ISSN 1392-3196 / e-ISSN 2335-8947

Zemdirbyste-Agriculture, vol. 107, No. 2 (2020), p. 139-146

DOI $10.13080 /$ z-a.2020.107.018

\title{
Changes in Sitona lineatus abundance in faba beans as influenced by the air temperature and rainfall in the three decades
}

\author{
Mohammad ALMOGDAD, Kęstutis TAMOŠIŪNAS, Roma SEMAŠKIENE் \\ Lithuanian Research Centre for Agriculture and Forestry, Institute of Agriculture \\ Instituto 1, Akademija, Kèdainiai distr., Lithuania \\ E-mail: mohammad.almogdad@lammc.lt
}

\begin{abstract}
This research was carried out at the Institute of Agriculture, Lithuanian Research Centre for Agriculture and Forestry during the growing seasons of 1985-1988 and 2017-2018. The aim of this study was to analyse the changes in pea leaf weevil (Sitona lineatus L.) abundance in faba bean as affected by the air temperature and rainfall over the past more than 30 years. To collect adults of $S$. lineatus, yellow water traps were used during the growing season in both study periods. Larvae were counted in root nodules and in the surrounding soil. To determine the foliar damage, automatic leaf area scanner was used in 1985-1988, while in the second experimental period foliar damage was estimated by counting the number of $U$-shaped notches on leaves. The results showed that the trend of temperature maximums and minimums increased during three decades, and the amount of rainfall was uneven through the years. The increase in average air temperature was rapid in the recent three decades, which resulted in the change in the day-degrees required for $S$. lineatus. In the present study, the recorded accumulative thermal units over the two periods from 1985 to 1988 and from 2017 to 2018 showed a rise in day-degrees. The pyrethroid treatment was significantly effective against foliar damage, but it was ineffective in reducing the number of larvae and damaged nodules compared to the untreated.

Further research on the bioecology of $S$. lineatus and on the effective timing of its control is needed in Lithuania. The results obtained in this study supplement the already existing agricultural practices aimed at improvement of pea leaf weevil management in faba bean.
\end{abstract}

Key words: day-degrees, pea leaf weevil, pyrethroides, root nodules, Vicia faba.

\section{Introduction}

Insects are cold-blooded creatures taking on the temperature from their surroundings. Of all other environmental factors, the temperature may play the most decisive role (Bale et al., 2002). It is a major environmental factor affecting insects' development, survival and reproduction, as insects are very sensitive to ambient climate changes, especially temperature (Kambrekar et al., 2015). Precipitation is another factor that influences insect population. It affects insect pest enemies (Petzoldt, Seaman, 2006) and removes insects from plants by heavy rain (Reiners, Petzoldt, 2005). Soil flooding can be used as a control method for insects that overwinter in the soil (Vincent et al., 2003). Climate change may lead to changes in pests' distribution and development rates or may result in increasing overwintering period, number of generations and activity of natural enemies. Netherer and Schopf (2010) suggest that an increase in temperature and drought events in the southern areas of Europe will promote some insect species, which are less tolerant of thermal stress to move toward the northern areas. Climate change can also reduce plant resistance to insects and the efficacy of pesticides (Reddy, 2013). Also it usually impacts on the abundance, feeding behaviour, activity and reproduction of insects, where abundance increasing, for example, is associated with the rainy season (Vasconcellos et al., 2010). The main reason for decreasing abundance of arthropods is climate warming (Lister, Garcia, 2018). In warmer winter seasons, the abundance of insect species increases. This may be due to the increasing number of generations and shorter development period (Karuppaiah, Sujayanad, 2012).

Pea leaf weevil (Sitona lineatus L.) is endemic in Europe and the northern part of Africa, which has been introduced into different countries in the world (Olfert et al., 2012). S. lineatus is a subversive pest on legumes, and its damage depends mainly on the seasonality. It is considered the main pest on pea as a spring crop, while not on the winter crop. In addition, the relative air humidity can also affect development of growth stages (Mansoor-ul-Hasan et al., 2017). Temperature is an influential factor on the development stages and fecundity of $S$. lineatus and its infestation potential.

Please use the following format when citing the article:

Almogdad M., Tamošiūnas K., Semaškienè R. 2020. Changes in Sitona lineatus abundance in faba beans as influenced by the air temperature and rainfall in the three decades. Zemdirbyste-Agriculture, 107 (2): 139-146. DOI 10.13080/z-a.2020.107.018 
For example, Arbab and McNeill (2011) found that the period of embryo development in $S$. lepidus was about 10 and 55 days at $28^{\circ} \mathrm{C}$ and $9^{\circ} \mathrm{C}$, respectively, while the embryo died at $35^{\circ} \mathrm{C}$. In another study, the development rate of immature stages in $S$. lineatus decreased at a temperature above $30^{\circ} \mathrm{C}$. A female laid up to 40 eggs daily at $25^{\circ} \mathrm{C}$ (Lerin, 2004). Understanding of the response of pest abundance to climate change is important in order to reduce chemical management.

In Lithuania, the seasonal variation in the air temperature and precipitation decreased at the beginning of the fourth decade of the $20^{\text {th }}$ century. Comparison of temperatures in the $21^{\text {st }}$ century to those in the period from 1961-1990 showed an increase in the temperature (Bosnjakovic, Haber, 2015). During the last 15-30 years, the average temperature in Lithuania has risen. The tendency that the amount of precipitation in Lithuania is increasing in the cold period and decreasing in the warm period has been observed (LHS, http://www.meteo. $1 \mathrm{t} / \mathrm{lt} / \mathrm{klimato}-\mathrm{kaita})$. Compared to the $20^{\text {th }}$ century, the average annual temperature in Lithuania increased by $0.7-0.9^{\circ} \mathrm{C}$, which agrees with Ozolinčius (2012), who have documented that the thermal period in spring and autumn has increased.

Changes in the abundance of Sitona lineatus in faba bean as influenced by the air temperature and rainfall over the past more than 30 years are presented in this study.

\section{Materials and methods}

Research site. The research was carried out in two periods: 1985-1988 and 2017-2018, at the Institute of Agriculture, Lithuanian Research Centre for Agriculture

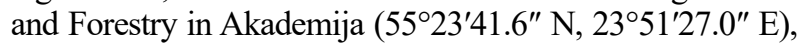
Kedainiai district, situated in Central Lithuania.

Weather data. Monthly temperatures and rainfall during the growing season months (April to September) between 1984 and 2018 were obtained from Dotnuva Meteorological Station located about $0.5 \mathrm{~km}$ from the experimental site. The maximum and minimum temperature and the total rainfall were recorded daily. The average of temperatures was estimated for every 10 days, and then the average of the three values was calculated.

Insect sampling. In each study field, six yellow water traps were distributed $6 \mathrm{~m}$ from each other in six locations to detect the appearance time and abundance of pea leaf weevil (Sitona lineatus L.). Beetle adults were collected weekly from the traps and transferred to the laboratory for analysis, where individuals were counted. Also, a $0.25 \mathrm{~m}^{2}$ frame was used in two places of each plot (size is $2 \times 10 \mathrm{~m}=20 \mathrm{~m}^{2}$ ) to count $S$. lineatus during the growing seasons of 1985, 1986, 1987, 1988, 2017 and 2018.

Insecticide treatments. In both experimental periods (1985-1988 and 2018), the pyrethroid insecticides were applied according to the local threshold. The products used in the study are described in Table 1.

Foliar damage and larvae number of S. lineatus. In 1985-1988, the foliar area was measured by leaf area scanner automation area meter AAM-7 (Kayashi Denko Ltd., Japan). At growth stages BBCH 12, 14 and 39, 100

Table 1. Description of insecticides used in the study

\begin{tabular}{cc}
\hline Product title and rate & Active ingredient (a.i.) \\
\hline Ambush $0.8 \mathrm{~kg} \mathrm{ha}^{-1}$ & permethrin $250 \mathrm{~g} \mathrm{~L}^{-1}$ \\
Cyperkill 500 EC 0.05 L ha-1 & cypermethrin $500 \mathrm{~g} \mathrm{~L}^{-1}$ \\
\hline
\end{tabular}

leaves of faba bean plants, differing in size, were taken randomly from the treated and untreated plots, and then they were passed through equipment sensors to calculate the total leaf area. To determine larvae number, the whole roots of 10 plants of faba bean were collected randomly per plot, and after washing the number of larvae in the nodules was counted under the magnifier. In 2018, U-shaped notches on leaves from 10 randomly sampled plants per plot were counted at growth stages $\mathrm{BBCH}$ $11,12,13,14$ and 16. At growth stage BBCH 16, due to high number of notches per plant, a scale for damage percentage estimation with 5 levels for peripheral injury ratio $(0-$ no notches, $1-10 \%, 2-25 \%, 3-75 \%$ and 4 $-100 \%$ ) was used. To count larvae at the full flowering stage $\mathrm{BBCH} 65$ roots of 10 plants with surrounding soil were collected randomly per plot. The soil from each sample was soaked in salty $(10 \%)$ water then was passed through a $250 \mu \mathrm{m}$ sieve to count $S$. lineatus larvae. Roots were washed at the laboratory, and then the number of damaged and undamaged nodules was counted.

Estimating the day-degrees. To calculate the day-degrees (thermal units) during the two experimental periods (1985-1988 and 2017-2018), the following formula was used (McMaster, Wilhelm, 1997):

$$
\mathrm{DD}=\frac{\mathrm{D}_{\max }+\mathrm{D}_{\min }}{2}-\mathrm{LDT},
$$

where DD is the day-degrees, $\mathrm{D}_{\max }$ and $\mathrm{D}_{\text {min }}$ - the daily maximum and minimum temperature, respectively, LDT - the lower developmental threshold, which is the base temperature for adults to finish their overwintering and to be active. That temperature was determined by Hans (1959). In the formula, if $\left(\left(D_{\max }+D_{\min }\right) / 2\right)$ is less than LTD, there is no accumulation of thermal units and $\mathrm{DD}=0$. Day-degrees accumulation was tracked and recorded. The average of day-degrees under the current (2017-2018) weather conditions was compared with previous (1985-1988).

Statistical analysis. The data were recorded and analysed statistically by the software $S A S$, version 7.15 (SAS Institute Inc., USA). The significance of differences was estimated by Duncan's multiple range test at the probability level $P<0.05$.

\section{Results and discussion}

Changes in the air temperature and amount of precipitation in the central part of Lithuania between 1984 and 2018. As shown in Figure 1, during 35 years, the trend of temperature showed an increase during the growing season's period. This is in line with the steadily rising temperatures documented in Europe as an outcome of global climate change (Pasqui, Di Giuseppe, 2019). Also, this is consistent with temperature increase in Europe over the past 36 years, which was $1^{\circ} \mathrm{C}$ above average (Bukantis et al., 2013). During the observation period, the lowest annual temperature average $\left(+11.9^{\circ} \mathrm{C}\right)$ was recorded in 1987 , and the highest one $\left(+16.6^{\circ} \mathrm{C}\right)$ was recorded in 2018.

As shown in Figure 2, the biggest drop in the deviation from the annual air temperature average was $-1.2^{\circ} \mathrm{C}$ recorded in 1987 , while in 2018 there was recorded the biggest increasing $\left(+3.6^{\circ} \mathrm{C}\right)$ in the deviation from the annual temperature average.

As shown in Figure 3, April had the highest deviation increasing from the air temperature average $\left(+1.6^{\circ} \mathrm{C}\right)$, while June had the lowest $\left(+0.3^{\circ} \mathrm{C}\right)$. 


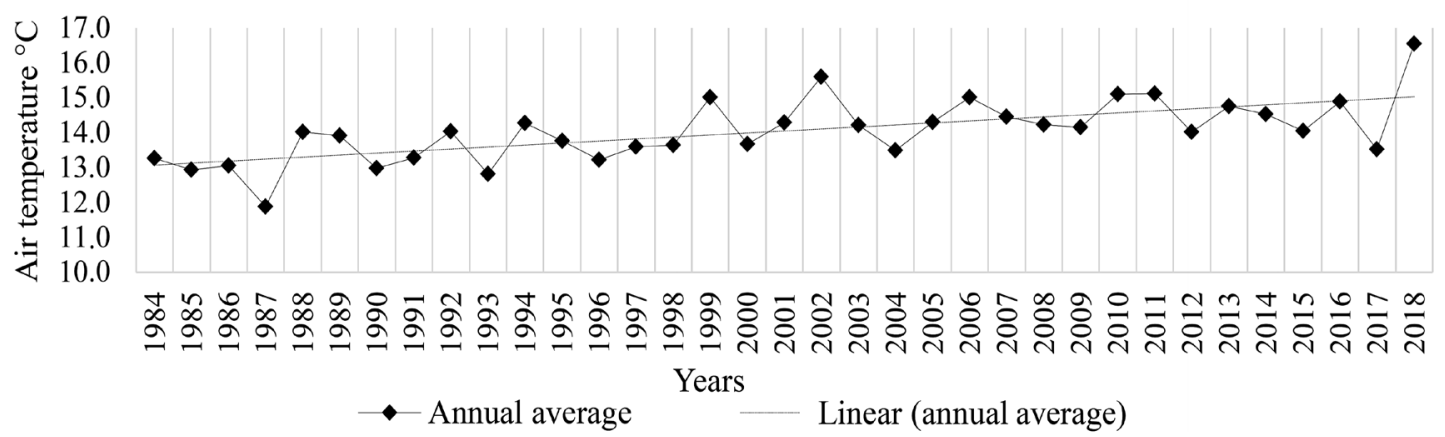

Figure 1. The trend of annual air temperature during the growing season (April-September) (data of Dotnuva Meteorological Station)

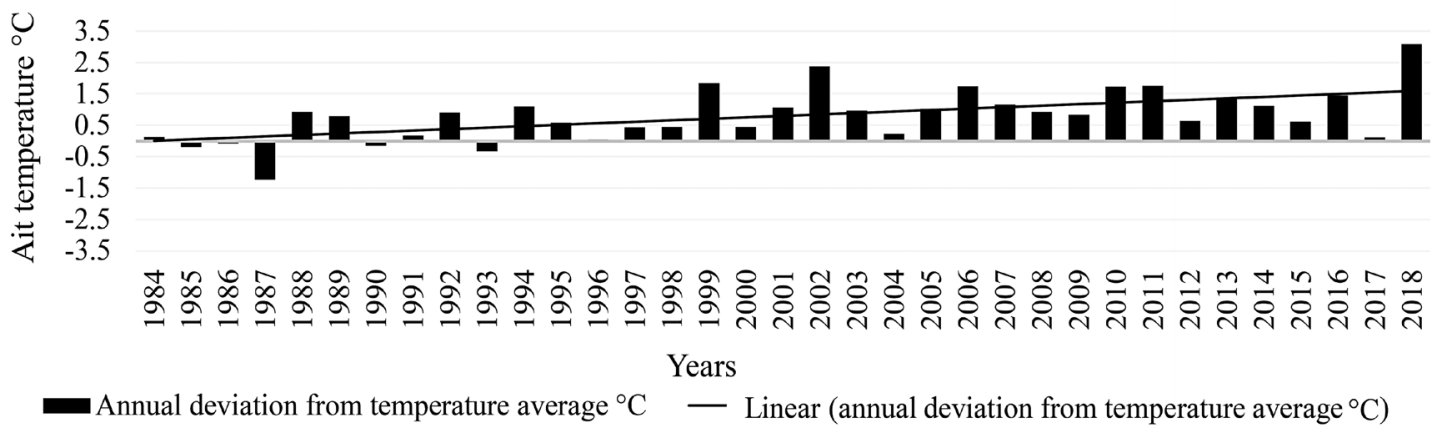

Figure 2. The trend of annual deviation from the air temperature average during the growing season (April-September) (data of Dotnuva Meteorological Station)

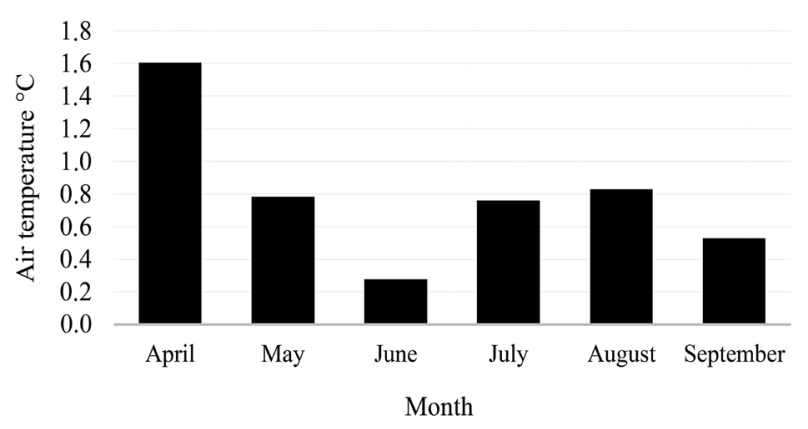

Figure 3. The deviation from the air temperature average during the growing season (1984-2018) (data of Dotnuva Meteorological Station)
The changes in daily maximum and minimum air temperature were also noticed. As shown in Figure 4, in 2017-2018, they were higher than in 1985-1988 by $2.7^{\circ} \mathrm{C}$ and $1.4^{\circ} \mathrm{C}$, respectively. So the trend of temperature maximums and minimums increased during 35 years. The increase in temperature was consistent with Bukantis et al. (2013), who reported that in Lithuania, the daily sunlight hours in 1991-2010 were higher than $1961-1990$ by $80-200$ hours, and the annual increase in temperature was $0.7-1{ }^{\circ} \mathrm{C}$ in the period $1991-2010$ compared to 1961-1990. However, a report by the US Environmental Protection Agency (EPA, https://www. epa.gov) noted that global warming does not occur because of an increase in solar output but because of the greenhouse gases (Zohdy et al., 2016).

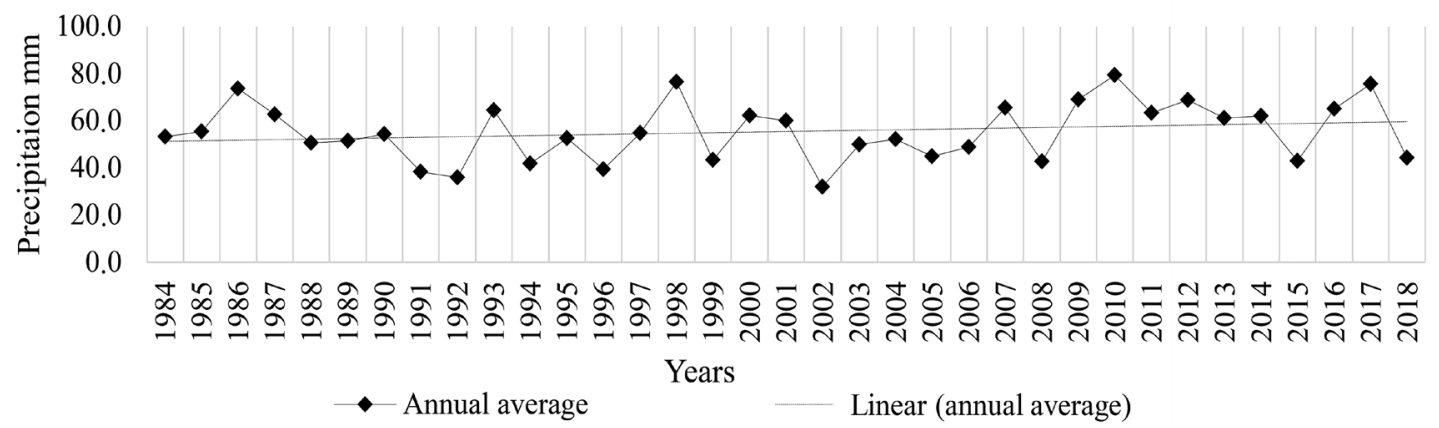

Figure 4. The trend of total annual precipitation (1984-2018) during the growing season (April-September) (data of Dotnuva Meteorological Station)

The precipitation amounts showed that the precipitation patterns are not homogenous through the years. The driest year was 2002, while since 2009 a new wet period began and the trend for precipitation showed an increase over 35 years, although there were frequent droughts in 1991, 1992, 2002, 2015 and 2018.
In 1984-1993, the annual precipitation average in 1999-2018 increased by $16.9 \%$ compared to 1984 1993. But that increase was not in all months, in June and August it decreased and in April, May, July and September it increased. This is consistent with Bukantis et al. (2013), who found that the increase in annual precipitation average 
occurred not in all months in 1991-2010 compared to 1961-1990. During the two periods of research (19851988 and 2017-2018), three years (1986, 1987 and 2017) exceeded the overall precipitation average.

An increase in the precipitation rate may occur because of the rapid increase in water cycle associated with global warming (Bukantis et al., 2013). This increase in temperature average may continue according to the forecasts, which indicate an increase in temperature and an annual reduction in snow cover (Bosnjakovic, Haber, 2015). The climatic change may only include extremely hot summer and increasing precipitation amount in winter (Andersson, 2013).

Sitona lineatus is a major spring pest of faba bean (Vicia faba L.). According to the Hamon et al. (1987), spring flight of this insect pest begins if temperatures are above $12.5^{\circ} \mathrm{C}$. The increase in temperature from 1984 to recent times suggests an earlier spread and increase of abundance of this pest.
Abundance of $S$. lineatus in faba been; results for 1985-1988 experiment. As shown in Figure 5, at all growth stages, abundance of $S$. lineatus differed between the study years. The highest abundance of beetles was in the initial stages of the faba bean growing. There are several reasons for that; the most important factor was particular weather, which determined the dynamics of their number in individual years. In 1985, the abundance of $S$. lineatus adults was significantly higher than in the other growing seasons during the research years. This may be due to the fact that the weather in 1985 was suitable for pest development with the temperature average in May and June $+1.6^{\circ} \mathrm{C}$ higher than normal $\left(14.8^{\circ} \mathrm{C}\right)$. In addition, the air humidity and soil moisture content were sufficient. In 1985, S. lineatus adults migrated to faba bean field before emergence of the shoots through the soil surface, and there was one peak of $S$. lineatus abundance at growth stages BBCH 12-30.

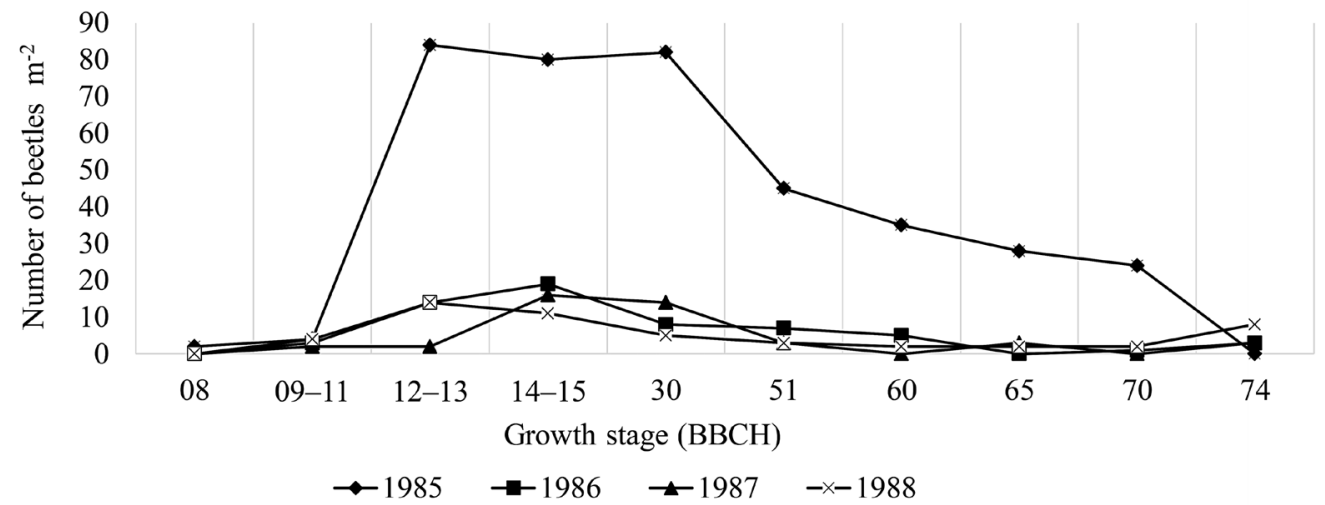

Figure 5. The abundance of Sitona lineatus at different growth stages (1985-1988)

Studies on insect flight activity showed that hightemperature promoted the insects to start flight earlier due to various internal factors that encourage to start the flight (Cooter, 2018). The high temperatures speed up metabolism, which immediately raises pest activity and ends the diapause faster (Jaworski, Hilszczański, 2013; Lemoine et al., 2014). In 1986, 1987 and 1988, the migration of adults to the field coincided with shoot emergence and there were two peaks of abundance at the same growth stages $(\mathrm{BBCH} 12-15$ and $\mathrm{BBCH} 74)$ in those years.

As shown in Figure 6, in 1985, the S. lineatus was most intensively feeding on the leaves in the untreated plots. The leaf area was the smallest in all growth stages of faba bean. Meanwhile, the treatment by insecticide permethrin resulted in the largest leaf area at the growth stage $\mathrm{BBCH} 30$ an increase of about $4.5 \mathrm{~cm}^{2}$. In 1986, the leaf area was similar to that in 1985, when the beetles were most intensively feeding on the leaves in the untreated plots. In 1987, the abundance of $S$. lineatus was low due to the chilly weather in spring and colder than usual winter, which has been found to decrease the abundance of insects in the next growing season (Reddy, 2013). At low abundance, a.i. permethrin gave very good efficacy at the growth stage BBCH 14-15. Some differences between the treated and untreated plots were also noticed in 1988, especially at growth stage $\mathrm{BBCH}$ 30 , when a.i. permethrin gave $3.6 \mathrm{~cm}^{2}$ larger leaf area compared to the untreated.

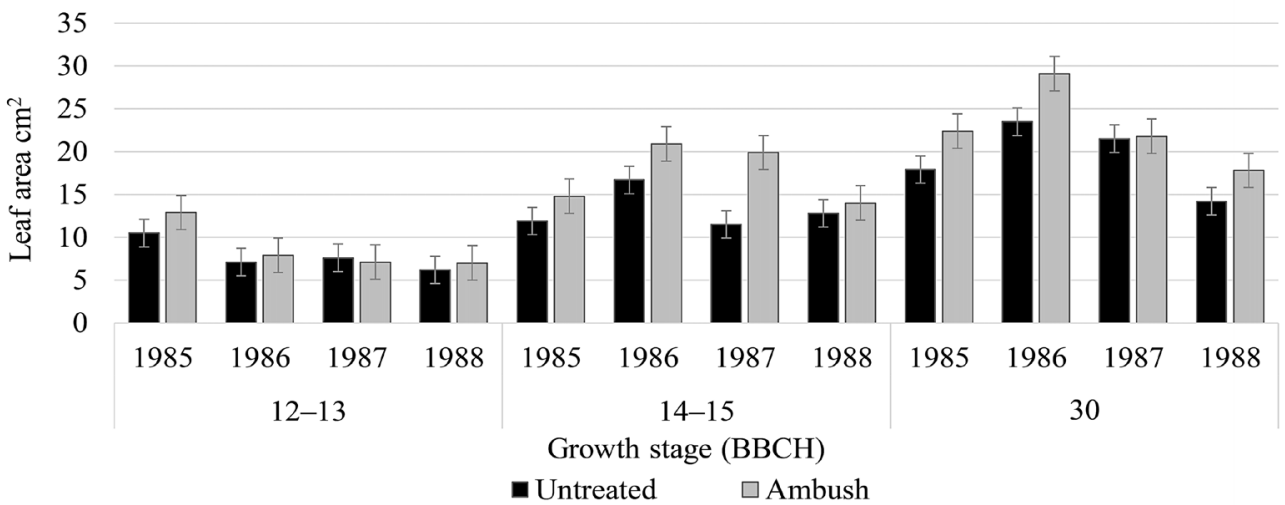

Figure 6. Faba bean leaf area at different growth stages (1985-1988) 
Precipitation and drought are important factors that increased insect pest prevalence through changing the physiology of host plants, whose susceptibility to insects feeding and appearance is heightened by the lack of precipitation or heat waves (Hart et al., 2017). As shown in Figure 7, there were almost no larvae at the tested growth stages in the different years. This does not agree with the studies, which found that the root nodules can be damaged by larvae at all growth stages (Jackson, MacDougall, 1920). At all the times when the larvae were present, insecticide permethrin showed good efficacy against them compared to the untreated.

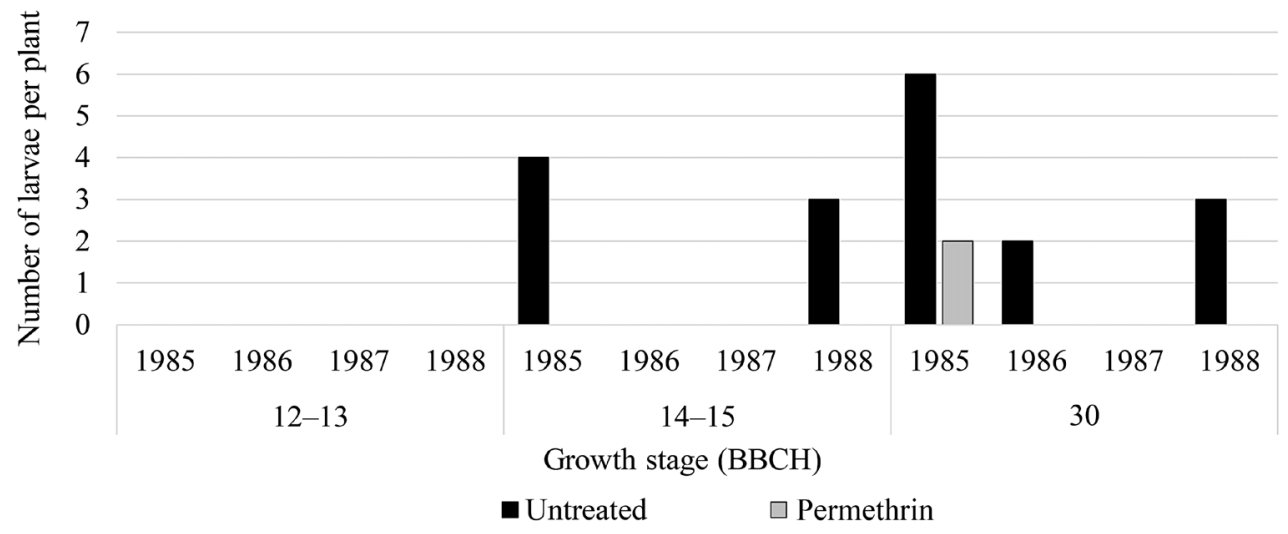

Figure 7. The number of Sitona lineatus larvae in the root nodules of faba bean (1985-1988)

Results for 2017-2018 experiment. As shown in Figure 8 , there were two peaks of $S$. lineatus abundance in both 2017 and 2018 at the same growth stages of faba bean. The first peak occurred during the flower opening period (BBCH 60-63), and the second one occurred, when all pods had reached the final length (BBCH 79). The number of generations of insects is highly correlated with global warming. The number of generations per year may increase as the insects tend to grow faster in the warmer climate (Jaworski, Hilszczański, 2013). S. lineatus speeds up the development and extends the period and rate of reproduction, which in turn will increase insect abundance and crop damage (Reddy, 2013; Raza et al., 2015). The trend of the abundance of $S$. lineatus was relatively similar in both 2017 and 2018 at almost all growth stages of faba bean with some exceptions. In 2017, the first appearance $S$. lineatus adults in the traps was compatible with the first leaf unfolding at growth stage $\mathrm{BBCH} 11$. It was a bit later compared to 2018, when the first appearance was just before shoot emergence through the soil surface at growth stage $\mathrm{BBCH} 08$. This was due to the higher temperature average in April and May in $2018\left(+4.3^{\circ} \mathrm{C}\right)$ than in 2017 $\left(+4.4^{\circ} \mathrm{C}\right)$ for the same period. When $80 \%$ of faba bean pods became ripe, the abundance of $S$. lineatus in 2017 was significantly higher than in 2018.

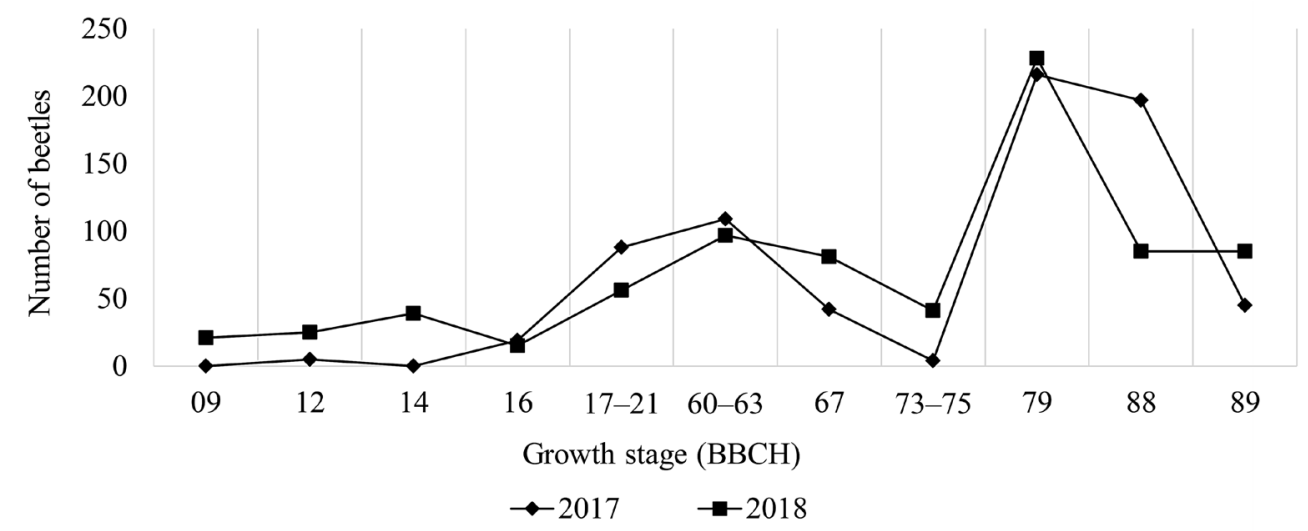

Figure 8. The abundance of Sitona lineatus in 6 traps

As shown in Table 2, adult density in untreated plots at the faba bean growth stage $\mathrm{BBCH} 12$ was quite high $\left(7.5\right.$ beetles per $\left.\mathrm{m}^{2}\right)$. Insecticide cypermethrin did not give a significant difference of pests compared to the untreated at growth stages $\mathrm{BBCH} 12$ and 13 or later. Meanwhile, foliar damage severity was significantly the lowest in the treated plots (15.32 notches per plant) compared to the untreated (30.8 notches per plant). The protective effect of a.i. cypermethrin against foliar damage continued until growth stage $\mathrm{BBCH} 16$. In 2018 , the percentage of damaged nodules ranged from $49.3 \%$ to $56.3 \%$. There were no significant differences in effect on the number of larvae between the treatments. Slightly lower percentage of damaged nodules was observed in the treated plots compared to the untreated. This agrees with Vankosky (2010), who found that the pea plants treated with pesticides did not significantly differ from the untreated ones in the number of damaged nodules.

The difference in the pest severity depends on several factors, the most important of which being the appropriate environmental conditions that favour the development and shortening of stages (embryo, larva and pupa). Studies showed that the cold weather conditions in spring led to the appearance of $S$. lineatus at the more advanced plant growth stages compared to warmer weather conditions (Cárcamo, Vankosky, 2011). The complex 
Table 2. The mean number of Sitona lineatus per $1 \mathrm{~m}^{2}$, number of crescent notches on leaves at the two faba bean growth stages, number of larvae around the plant and percentage of damaged nodules in 2018

\begin{tabular}{|c|c|c|c|c|c|c|}
\hline \multirow{3}{*}{ Treatment } & \multicolumn{4}{|c|}{ Growth stage } & \multirow{3}{*}{$\begin{array}{l}\text { Number of } \\
\text { larvae }\end{array}$} & \multirow{3}{*}{$\begin{array}{c}\text { Percentage } \\
\text { of damaged } \\
\text { nodules } \\
\%\end{array}$} \\
\hline & \multicolumn{2}{|c|}{ BBCH 12} & \multicolumn{2}{|c|}{ BBCH 13} & & \\
\hline & $\begin{array}{l}\text { number of } \\
\text { beetles }\end{array}$ & $\begin{array}{c}\text { number of } \\
\text { notches }\end{array}$ & $\begin{array}{l}\text { number of } \\
\text { beetles }\end{array}$ & $\begin{array}{c}\text { number of } \\
\text { notches }\end{array}$ & & \\
\hline Untreated & $7.5 \pm 1.70 \mathrm{a}$ & $9.75 \pm 0.64 b$ & $9.5 \pm 3.09 \mathrm{a}$ & $30.77 \pm 1.62 b$ & $3.32 \pm 0.63 \mathrm{a}$ & $56.36 \pm 2.89 \mathrm{a}$ \\
\hline Cypermethrin & $4 \pm 2.30 \mathrm{a}$ & $7.57 \pm 0.96 \mathrm{a}$ & $5.5 \pm 1.70 \mathrm{a}$ & $15.32 \pm 1.08 \mathrm{a}$ & $3.27 \pm 0.32 \mathrm{a}$ & $49.31 \pm 2.42 \mathrm{a}$ \\
\hline
\end{tabular}

Note. Means within a column followed by the same letters are not significantly different according to Duncan's multiple-range test.

relationship between humidity and temperature is one of the most important factors affecting hatching. For example, the appropriate relative humidity for egg hatching for $S$. lividipes and $S$. hispidulus was above $76 \%$, while for $S$. crinitus and $S$. lineatus it was more than $56 \%$. No eggs were hatched below those values. Despite the ideal relative humidity, the increase in air temperature above $25^{\circ} \mathrm{C}$ resulted in a decrease in egg hatching rate for $S$. lividipes, $S$. hispidulus and S. crinitus, while for $S$. lineatus egg hatching was not influenced up to $29^{\circ} \mathrm{C}$ (Melamed-Madjar, 1966).

In our study, none of the foliar treatments was efficient in reducing the number of $S$. lineatus larvae. It also agrees with Seidenglanz et al. (2010), who found that the seed and foliar treatments were not effective against $S$. lineatus larvae. A study on seed treatments conducted by Gospodarek et al. (2016) reported no significant effect of seed treatments at different times on the number of damaged nodules. On the other hand, high temperatures negatively affect the efficacy of pyrethroid insecticides by accelerating their degradation (Reddy, 2013).

Estimating day-degrees for S. lineatus. As shown in Figure 9, under current climate conditions the average amount of day-degrees required for $S$. lineatus adults to finish their overwintering and to be active was 196.6 thermal units (about 22\% higher) compared to 161 thermal units three decades ago.

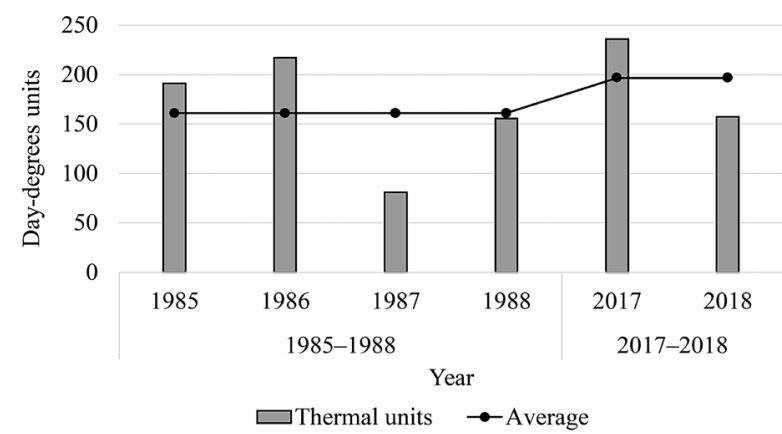

Figure 9. Day-degrees units for Sitona lineatus under ancient and current climate conditions

At the present time, the day-degrees decreased compared with the previous data for the same studied area. The highest difference for required day-degrees was found between 1987 and 2017, where they were 80.8 and 235.9 thermal units, respectively, while other years gave a slight change in the required thermal units. There was no clear correlation between the increase in the annual temperature rate and the required thermal units for $S$. lineatus incidence. It depended on the daily temperature average in the month, which preceded planting the host crop. The period required to start S. lineatus activity decreased, when the daily temperatures were much higher than the threshold temperature compared to the temperatures close to the threshold. Therefore, the relationship between $S$. lineatus activity rate and the daily temperature was not linear. This may be due to a change in the rate of metabolism at different daily temperatures. That is similar to what Arbab et al. (2008) found, where the relationship between the temperature and insect growth rate was not linear and development rate increased to a maximum at the optimum temperature but quickly decreased to zero at the fatal temperature. Day-degrees help farmers to predict the time of pests' appearance and their flight peaks in the fields as a way of pest management (Zohdy et al., 2016). Day-degrees varied between the study years, which is in line with Brust et al. (2009), who found that this variation was caused by the soil temperature and solar radiation (Zohdy et al., 2016).

\section{Conclusions}

1. The increase in average air temperature has been rapid over the recent three decades, which resulted in the change in the day-degrees required for Sitona lineatus in faba bean. In the present study, the recorded accumulative thermal units along the two periods from 1985 to 1988 and from 2017 to 2018 showed a rise in day-degrees.

2. Results showed that the pyrethroid treatment was significantly effective against foliar damage, but it was inefficient in reducing the number of larvae and the damaged nodules compared to the untreated.

3. Further research on the correct insecticide application timing and on the bioecology of $S$. lineatus in the region of Lithuania is needed. The results obtained in this research supplement the already existing agricultural practices aimed at improvement of $S$. lineatus management in faba bean.

\section{Acknowledgements}

We would like to extend our thanks to the technical team of the Department of Plant Pathology and Protection of Institute of Agriculture, Lithuanian Research Centre for Agriculture and Forestry for their contribution to this research. 


\section{References}

1. Andersson L. 2013. Baltadapt strategy for adaptation to climate change in the Baltic Sea region: a proposal preparing the ground for political endorsement throughout the Baltic Sea Region. Danish Meteorological Institute, Denmark

2. Arbab A., McNeill M. R. 2011. Determining suitability of thermal development models to estimate temperature parameters for embryonic development of Sitona lepidus Gyll. (Coleoptera: Curculionidae). Journal of Pest Science, 84 (3): 303-311. https://doi.org/10.1007/s10340-011-0360-7

3. Arbab A., Kontodimas D. C., McNeill M. R. 2008. Modeling embryo development of Sitona discoideus Gyllenhal (Coleoptera: Curculionidae) under constant temperature. Environmental Entomology, 37 (6): 1381-1388. https://doi.org/10.1603/0046-225X-37.6.1381

4. Bale J. S., Masters G. J., Hodkinson I. D., ..., Whittaker J. B. 2002. Herbivory in global climate change research: direct effects of rising temperature on insect herbivores. Global Change Biology, 8 (1): 1-16. https://doi.org/10.1046/j.1365-2486.2002.00451.x

5. Bosnjakovic B., Haber I. M. 2015. Climate changes and adaption policies in the Baltic and the Adriatic regions. UTMS Journal of Economics, 6 (1): 21-39.

6. Brust M. L., Hoback W. W., Wright R. J. 2009. Degreeday requirements for eight economically important grasshoppers (Orthoptera: Acrididae) in Nebraska using field data. Environmental Entomology, 38 (5): 1521-1526. https://doi.org/10.1603/022.038.0521

7. Bukantis A., Ignatavičius G., Satkūnas J., Sinkevičius S., Šulijienė G., Vasarevičius S., Veteikis D. 2013. Lithuania's environment: state, processes and trends. Environmental Protection Agency, $214 \mathrm{p}$.

8. Cárcamo H., Vankosky M. 2011. Managing the pea leaf weevil in field peas. Prairie Soils and Crops, 4: 77-85.

9. Cooter R. 2018. Swarm flight behavior in flies and locusts. Wheeler C., Goldsworthy G. (eds). Insect flight. CRC Press, p. 165-204. https://doi.org/10.1201/9781351073585-8

10. Gospodarek J., Gleń-Karolczyk K., Boligłowa E. 2016. The effect of non-chemical and chemical broad bean protection against diseases and pests on the feeding of pea weevils (Sitona spp.). Journal of Research and Applications in Agricultural Engineering, 61 (3): (151-155).

11. Hamon N., Bardner R., Allen-Williams L., Lee J. B. 1987. Flight periodicity and infestation size of Sitona lineatus. Annals of Applied Biology, 111 (2): 271-284. https://doi.org/10.1111/j.1744-7348.1987.tb01453.x

12. Hans H. 1959. Beiträge zur Biologie von Sitona lineatus L. Zeitschrift für angewandte Entomologie, 44 (4): 343-386 (in German).

https://doi.org/10.1111/j.1439-0418.1959.tb00933.x

13. Hart J., Veblen T., Schneider D., Molotch P. 2017. Summer and winter drought drive the initiation and spread of spruce beetle outbreak. Ecology, 98 (10): 2698-2707. https://doi.org/10.1002/ecy.1963

14. Jackson D. J., MacDougall K. S. 1920. Bionomics of weevils of the genus Sitones injurious to leguminous crops in Britain. Annals of Applied Biology, 7 (2-3): 269-298. https://doi.org/10.1111/j.1744-7348.1920.tb05310.x

15. Jaworski T., Hilszczański J. 2013. The effect of temperature and humidity changes on insects development their impact effect of temperature and humidity changes on insects development and their impact on forest ecosystems in the context of expected climate change on forest ecosystems. Leśne Prace Badawcze (Forest Research Papers), 74 (4): 345-355. https://doi.org/10.2478/frp-2013-0033

16. Kambrekar N., Guledgudda S., Katti A., Mohankumar 2015. Impact of climate change on insect pests and their natural enemies Karnataka Journal of Agricultural Sciences, 28 (5): 814-816.
17. Karuppaiah V., Sujayanad G. K. 2012. Impact of climate change on population dynamics of insect pests. World Journal of Agricultural Sciences, 8 (3): 240-246.

18. Lemoine N. P., Burkepile D. E., Parker J. D. 2014. Variable effects of temperature on insect herbivory. PeerJ - the Journal of Life and Environmental Sciences, 2: e376. https://doi.org/10.7717/peerj.376

19. Lerin J. 2004. Modeling embryonic development in Sitona lineatus (Coleoptera: Curculionidae) in fluctuating temperatures. Environmental Entomology, 33 (2): 107-112. https://doi.org/10.1603/0046-225X-33.2.107

20. Lister B. C., Garcia A. 2018. Climate-driven declines in arthropod abundance restructure a rainforest food web. Proceedings of the National Academy of Sciences, 115 (44): e10397-E10406. https://doi.org/10.1073/pnas.1722477115

21. Mansoor-ul-Hasan A. A., Jafir M., Javed M. W., Shehzad M., Chaudhary M. Z., Aftab M. 2017. Effect of temperature and relative humidity on development of Sitophilus oryzae L. (Coleoptera: Curculionidae). Journal of Entomology and Zoology Studies, 5 (6): 85-90.

22. McMaster S., Wilhelm W. 1997. Growing degree-days: one equation, two interpretations. Agricultural and Forest Meteorology, 87 (4): 291-300.

https://doi.org/10.1016/S0168-1923(97)00027-0

23. Melamed-Madjar V. 1966. Observations on four species of Sitona (Coleoptera, Curculionidae) occurring in Israel. Bulletin of Entomological Research, 56 (3): 505-514. https://doi.org/10.1017/S0007485300056558

24. Netherer S., Schopf A. 2010. Potential effects of climate change on insect herbivores in European forests - general aspects and the pine processionary moth as specific example. Forest Ecology and Management, 259 (4): 831838. https://doi.org/10.1016/j.foreco.2009.07.034

25. Olfert O., Weiss R. M., Cárcamo H. A., Meers S. 2012. The influence of abiotic factors on an invasive pest of pulse crops, Sitona lineatus (L.) (Coleoptera: Curculionidae), in North America. Psyche: A Journal of Entomology, 2012: ID 746342. https://doi.org/10.1155/2012/746342

26. Ozolinčius R. 2012. Possible effects of climate change on forest biodiversity, tree growth and condition: review of research in Lithuania. Baltic Forestry, 18 (1): 156-167.

27. Pasqui M., Di Giuseppe E. 2019. Climate change, future warming, and adaptation in Europe. Animal Frontiers, 9 (1): 6-11. https://doi.org/10.1093/af/vfy036

28. Petzoldt C., Seaman A. 2006. Climate change effects on insects and pathogens. Climate change and agriculture: promoting practical and profitable responses, vol. 3, p. 6-16.

29. Raza M. M., Khan M. A., Arshad M., Sagheer M., Sattar Z., Shafi J., Haq E., Ali A., Aslam U., Mushtaq A., Ishfaq I., Sabir Z., Sattar A. 2015. Impact of global warming on insects. Archives of Phytopathology and Plant Protection, 48 (1): 84-94. https://doi.org/10.1080/03235408.2014.882132

30. Reddy P. P. 2013. Impact of climate change on insect pests, pathogens and nematodes. Pest Management in Horticultural Ecosystems, 19 (2): 225-233.

31. Reiners S., Petzoldt C. H. C. 2005. Integrated crop and pest management guidelines for commercial vegetable production. Cornell University, Switzerland, $317 \mathrm{p}$.

32. Seidenglanz M., 1, J., Smýkalová I., Poslušná J., Kolařík P. 2010. Differences between the effects of insecticidal seed and foliar treatments on pea leaf weevils (Sitona lineatus L.) in the field pea (Pisum sativum L.). Plant Protection Science, 46 (1): 25-33. https://doi.org/10.17221/34/2009-PPS

33. Vankosky M. A. 2010. Integrated pest management of Sitona lineatus L. (Coleoptera: Curculionidae) in crops of Pisum sativum L. (Fabales: Fabaceae) in Western Canada: master thesis. University of Alberta, Canada, 212 p. 
34. Vasconcellos A., Andreazze R., Almeida A. M., Araujo H. F., Oliveira E. S., Oliveira U. 2010. Seasonality of insects in the semi-arid Caatinga of northeastern Brazil. Revista Brasileira de Entomologia, 54 (3): 471-476. https://doi.org/10.1590/S0085-56262010000300019

35. Vincent C., Hallman G., Panneton B., Fleurat-Lessard F. 2003. Management of agricultural insects with physical control methods. Annual Review of Entomology, 48 (1): 261-281. https://doi.org/10.1146/annurev.ento.48.091801.112639
36. Zohdy N. Z. M., Abdel K. M., ElSayed M. 2016. Modeling the effects of temperature on population parameters of Chrotogonus homalodemus (Blanchard, 1836) (Orthoptera: Pyrgomorphidae). Species, 17 (56): 150-159.

ISSN 1392-3196 / e-ISSN 2335-8947

Zemdirbyste-Agriculture, vol. 107, No. 2 (2020), p. 139-146

DOI 10.13080/z-a.2020.107.018

\title{
Sitona lineatus gausumas pupose per tris dešimtmečius priklausomai nuo oro temperatūros ir kritulių kiekio
}

\author{
M. Almogdad, K. Tamošiūnas, R. Semaškienè
}

Lietuvos agrarinių ir miškų mokslų centro Žemdirbystės institutas

\section{Santrauka}

Tyrimai atlikti Lietuvos agrarinių ir miškų mokslų centro Žemdirbystès institute 1985-1988 ir 2017-2018 m. Tyrimų tikslas - išanalizuoti sitonų (Sitona lineatus L.) gausumo pokyčius pupose (Vicia faba L.) per daugiau nei tris dešimtmečius priklausomai nuo oro temperatūros kitimo ir kritulių kiekio. Abiem tyrimų laikotarpiais sitonų plitimui stebèti sezono metu buvo naudotos geltonosios vandens gaudyklès. Išsiritusios lervos skaičiuotos ant šaknų ir dirvožemyje, šaknų zonoje. Lapų pažeidimams nustatyti 1985-1988 m. atlikto tyrimo metu buvo naudotas automatinis lapų ploto skeneris. Antruoju tyrimo laikotarpiu buvo vertinta U formos iškarpų skaičiaus ant lapų procentinè išraiška. Tyrimų rezultatai parodè, kad minimalios ir maksimalios temperatūrų pokyčių tendencija per tris dešimtmečius padidejo, o kritulių kiekis tarp metų buvo pasiskirstęs netolygiai. Šiuo laikotarpiu vidutinè oro temperatūra sparčiai didejjo, kaip ir aktyvios temperatūros, reikalingos plisti S. lineatus. Tyrimų metu užregistruotos aktyvios temperatūros tarp dviejų laikotarpių nuo $1985 \mathrm{iki} 1988 \mathrm{~m}$. ir nuo $2017 \mathrm{iki} 2018 \mathrm{~m}$. parodè šių temperatūrų kilimą. Abiem tyrimų laikotarpiais purškimas piretroidų grupès insekticidu pupų lapų pažeidimus sumažino iš esmès, tačiau nepavyko sumažinti lervų ir pažeistų azotą fiksuojančių šaknų gumbelių kiekio.

S. lineatus bioekologijos ir efektyvios kontrolès tyrimai Lietuvoje turètų būti tęsiami. Šio tyrimo rezultatai gali prisidèti prie žemès ūkio praktikos, siekiant pagerinti šio kenkèjo valdymą ir sumažinti jo pupoms daromą žalą.

Reikšminiai žodžiai: aktyvios temperatūros, azotą fiksuojantys šaknų gumbeliai, piretroidai, sitonai, Vicia faba. 